\title{
Effects of Drying Techniques on Murtilla Fruit Polyphenols and Antioxidant Activity
}

\author{
Susana Alfaro ${ }^{1}$, Ana Mutis ${ }^{2}$, Andrés Quiroz ${ }^{2}$, Ivette Seguel ${ }^{3} \&$ Erick Scheuermann $^{4}$ \\ ${ }^{1}$ Programa de Doctorado en Ciencias de Recursos Naturales, Universidad de La Frontera, Temuco, Chile \\ ${ }^{2}$ Laboratorio de Ecología Química, Departamento de Ciencias Químicas y Recursos Naturales, Universidad de \\ La Frontera, Temuco, Chile \\ ${ }^{3}$ Centro Regional de Investigación Carillanca, Instituto de Investigaciones Agropecuarias - INIA, Casilla 58-D, \\ Temuco, Chile \\ ${ }^{4}$ Department of Chemical Engineering, Universidad de La Frontera, Casilla 54-D, Temuco, Chile and Center of \\ Food Biotechnology and Bioseparations, BIOREN-UFRO, Universidad de La Frontera, Chile \\ Correspondence: Erick Scheuermann, Department of Chemical Engineering, Universidad de La Frontera, Casilla \\ 54-D, Temuco, Chile. E-mail: ericks@ufrontera.cl
}

Received: June 9, 2014 Accepted: July 7, 2014 Online Published: July 9, 2014

doi:10.5539/jfr.v3n5p73 URL: http://dx.doi.org/10.5539/jfr.v3n5p73

\begin{abstract}
'Murtilla' (Ugni molinae Turcz) is a native Chilean species that belongs to the Myrtaceae family. It produces a small, globular fruit with pleasant flavor and recognized antioxidant activity. Convective hot-air and freeze drying are important techniques for fruit preservation, but their effect on murtilla fruit polyphenols and antioxidant activity has not yet been studied simultaneously. The objective of this study was to compare the effect of convective hot-air drying at 65 and $80{ }^{\circ} \mathrm{C}$ and freeze drying on total polyphenol content (TPC), total anthocyanin content (TAC), polyphenols and anthocyanins of the Red Pearl-INIA variety of fresh murtilla fruits as measured by HPLC and antioxidant activity (DPPH and ABTS). The freeze dried fruit retained higher values for TPC (2192.4 mg/100 g d.w.), TAC (13.4 mg/100 g d.w.), polyphenols (79.02 mg/100 g d.w. by HPLC) and anthocyanins $\left(0.188 \mathrm{mg} / 100 \mathrm{~g}\right.$ d.w. by HPLC) than the murtilla dried by convective hot-air at both 65 and $80^{\circ} \mathrm{C}$. The application of all treatments showed a positive increase in the DPPH (2945.4 to $3677.6 \mu \mathrm{mol} \mathrm{TE} / 100 \mathrm{~g}$ d.w.) and ABTS (2664.8 to $3397.2 \mu \mathrm{mol} \mathrm{TE} / 100 \mathrm{~g}$ d.w.) antioxidant activity of the dried murtilla compared to the DPPH (2111.1 $\mu$ mol TE/100 g d.w.) and ABTS $(2247.8 \mu \mathrm{mol} \mathrm{TE} / 100 \mathrm{~g}$ d.w.) of the fresh fruit. Freeze drying was the best technique for the retention of polyphenols and antioxidant activity from the fresh murtilla fruit. Therefore, freeze drying is recommended over convective hot-air drying at 65 and $80{ }^{\circ} \mathrm{C}$ when these bioactive compounds need to be preserved.
\end{abstract}

Keywords: Dehydration, Ugni molinae Turcz, convective hot-air drying, freeze drying, flavonoid and anthocyanin compounds

\section{Introduction}

'Murtilla', 'mutilla' or 'murta' (Ugni molinae Turcz) is a native Chilean species that produces a small berry fruit with a recognized fruity, sweet and floral aroma (Scheuermann et al., 2008) and antioxidant activity (Shene et al., 2009; Ruiz et al., 2010; Rubilar et al., 2011; Speisky, López-Alarcón, Gómez, Fuentes, \& Sandoval-Acuña, 2012; Alfaro et al., 2013). Polyphenolic compounds have been associated with antioxidant and antimicrobial activity for this native species (Shene et al., 2009; Ruiz et al., 2010; Rubilar et al., 2011; Alfaro et al., 2013). Ruiz et al. (2010) reported that the antioxidant activity of murtilla fruits was comparable with blueberry but lower than both maqui (Aristotelia chilensis) and calafate (Berberis microphylla) fruits. Two anthocyanins, cyanidin-3-glucoside and peonidin-3-O-glucoside, and the flavan-3-ols catechin and epicatechin were identified in murtilla fruits by the aforementioned authors, whereas Shene et al. (2009) reported myricetin glucoside, quercetin glucoside, quercetin glucuronide and quercetin dirhamnoside in a 50\% water/ethanol murtilla fruit extract.

Because this fruit is produced on a seasonal basis from March to May (Alfaro et al., 2013), drying is an adequate technique for its preservation and is able to maintain the antioxidant properties provided by its polyphenolic components (Kwok, Durance, \& Kitts, 2004; López et al., 2010; Mejia-Meza et al., 2010). Currently, there is 
limited range of the commercial dehydrated murtilla fruit, and all products are processed only using freeze drying, such as Murtaberry from Nativ for Life, Chile. Taking technology and cost into consideration, a good alternative to freeze drying would be conventional drying using convective hot-air. This technique has been researched for different berries, and it is routinely used by the food industry (Lewicki, 2006). However, the drawback of the convection drying is the decrease in the content of polyphenolic compounds as well as their antioxidant activity, which was reported for blueberries, Saskatoon berries and strawberries from the Kent and Elsanta cultivars. For these fruits, the decrease in total polyphenol content, total anthocyanin content and antioxidant activity varied in some cases from 24 to $82.6 \%$. The variation depended mainly on the temperature applied, which was normally between 50 and $90{ }^{\circ} \mathrm{C}$, and the drying time, which could be as long as $10 \mathrm{~h}$ (Kwok et al., 2004; Stojanovic \& Silva, 2007; Wojdyło, Figiel, \& Oszmianski, 2009; López et al., 2010; Mejia-Meza et al., 2010). Therefore, freeze drying, or lyophilization, is considered the best technique for the conservation of food, and it is recommended for preserving the polyphenols in berry fruits (de Torres, Díaz-Maroto, Hermosín-Gutiérrez, \& Pérez-Coello, 2010; Grace, Massey, Mbeunkui, Yousef, \& Lila, 2012).

Recent murtilla fruit drying studies have shown that the retention of the polyphenolic compounds and the antioxidant activity depends on the technique applied and primarily on the temperature used for conventional drying (Reyes, Bustos, Vásquez, \& Scheuermann, 2009; Reyes et al., 2010; Puente-Díaz, Ah-Hen, Vega-Gálvez, Lemus-Mondaca, \& Di Scala, 2013; Rodríguez et al., 2014). However, these studies used different genotypes of murtilla fruits and solely one drying technique in each study. Thus, no study has been performed to compare the effect of both conventional and freeze drying on the retention of polyphenols and their antioxidant activity using the same genotype or variety of murtilla fruits. Freeze drying should be better than convective hot-air drying to preserve the polyphenolic bioactive components reported in the literature for fresh murtilla fruit, but the use of adequate temperature for convective hot-air drying may also ensure the preservation of these compounds. Therefore, the objective of this study was to compare the effect of convective hot-air drying at $65^{\circ} \mathrm{C}$ (HAD 65 ${ }^{\circ} \mathrm{C}$ ) and $80^{\circ} \mathrm{C}\left(\mathrm{HAD} 80^{\circ} \mathrm{C}\right.$ ) as well as freeze drying (FD) on the polyphenolic compounds and the antioxidant activity of the Red Pearl-INIA variety of fresh murtilla (Ugni molinae Turcz) fruits.

\section{Materials and Methods}

\subsection{Plant Material}

Fresh murtilla (Ugni molinae Turcz) fruit, Red Pearl-INIA variety (Seguel \& Montenegro, 2010), was provided by the Agricultural Research Institute (INIA-Carillanca). Freshly harvested fruit $\left(16.8^{\circ} \mathrm{Brix}\right)$ was subjected to rapid freezing using liquid nitrogen $\left(-196^{\circ} \mathrm{C}\right)$ and was subsequently stored at $-20{ }^{\circ} \mathrm{C}$ in a freezer (Electrolux FE-26) for 20 days. This fruit was considered the fresh fruit (moisture content was $79 \%$ of the base weight) and was used in all experiments.

\subsection{Chemicals}

Quercetin, quercetin 3- $\beta$-glucoside, kaempferol, myricetin, catechin, gallic acid, cyanidin-3-glucoside, peonidin-3-O-glucoside, HPLC-grade methanol and sodium carbonate $\left(\mathrm{Na}_{2} \mathrm{CO}_{3}\right)$ were purchased from Sigma-Aldrich Co. (St. Louis, USA). HPLC-grade acetonitrile, formic acid, 2,2'azino-bis-(3-ethylbenzothiazoline-6-sulfonic acid) (ABTS), 6-hydroxy-2,5,7,8-tetramethylchroman-2-carboxylic acid (Trolox), 2,2-diphenyl-1-picrylhydrazyl (DPPH) and Folin-Ciocalteu reagent were purchased from Merck (Darmstadt, Germany).

\subsection{Drying Technique}

The murtilla fruits were dehydrated by freeze drying (FD) and convective hot-air drying at $65{ }^{\circ} \mathrm{C}\left(\mathrm{HAD} 65^{\circ} \mathrm{C}\right.$ ) and $80^{\circ} \mathrm{C}\left(\operatorname{HAD} 80^{\circ} \mathrm{C}\right)$. These temperatures were chosen because they were in the 50 to $90^{\circ} \mathrm{C}$ range reported for convective air drying of other berries (Kwok et al., 2004; Stojanovic \& Silva, 2007; López et al., 2010; Leusink et al., 2010) with similar size (diameter ranging from 9 to $11 \mathrm{~mm}$ ) and shape (globular) of murtilla fruit. The convective hot-air drying was carried out using an oven (Memmert model UFE 400, Germany) with convective air flow and temperature control. The murtilla fruit was dried at $65{ }^{\circ} \mathrm{C}$ for $8 \mathrm{~h}$ and $80{ }^{\circ} \mathrm{C}$ for $4.5 \mathrm{~h}$ until a final moisture content of 7\% wet base (w.b.) was reached. The air flow rate during HAD was $2 \mathrm{~m} \mathrm{~s}^{-1}$ and the fruit load density was $0.133 \mathrm{~g} \mathrm{~cm}^{-2}$. A Christ Alpha 1-2 Freeze dryer (Martin Christ, Germany) was used for freeze drying with round bottom flasks at a vacuum pressure of 0.05 millibar and the condenser temperature at $-55^{\circ} \mathrm{C}$. The drying time to reduce the moisture content to $5 \%$ w.b. was $48 \mathrm{~h}$. The final moisture content in the dried murtilla fruit was obtained by the equilibrium reached in each drying technique used.

\subsection{Extraction Procedure}

The extraction was carried out according to the methodology described by Alfaro et al. (2013). Fresh murtilla 
fruit $(6 \mathrm{~g})$ or dehydrated fruit $(1 \mathrm{~g})$ was ground in a mortar and transferred to a bottle, and then pre-warmed (30 $\left.{ }^{\circ} \mathrm{C}\right)$ methanol $(20 \mathrm{~mL})$ was added. The mixture was shaken in an incubator (GFL-3032, Germany) at $170 \mathrm{rpm}$ and $30{ }^{\circ} \mathrm{C}$ for $20 \mathrm{~min}$ and filtered (Whatman $\mathrm{N}^{\circ} 1$ ) by vacuum. The extract was protected from light and was used for the determination of total polyphenol content, total anthocyanin content, and antioxidant activity (DPPH and ABTS assays). For the determination of anthocyanins using HPLC, one portion of the extract was centrifuged at $1750 \times \mathrm{g}$ for $10 \mathrm{~min}$ at room temperature. Then, the supernatant was removed and frozen at $-20^{\circ} \mathrm{C}$. The polyphenols were determined directly from the extract. However, before HPLC analysis, the original extract or supernatant was concentrated to dryness using a rotary evaporator (Büchi R-210, Germany) at $30^{\circ} \mathrm{C}$ and 140 $\mathrm{rpm}$, and it was then redissolved in $5 \mathrm{~mL}$ of methanol:formic acid $(99: 1, \mathrm{v} / \mathrm{v})$. The evaluation of the polyphenolic compounds and the antioxidant activity was performed in triplicate for each drying techniques. All results were expressed per $100 \mathrm{~g}$ of dry weight to allow the comparison in polyphenols content and antioxidant activity between fresh and dried fruit. To calculate on basis of $100 \mathrm{~g}$ of dry weight, the dry matter of fresh (21\%), HAD 65 and $80{ }^{\circ} \mathrm{C}(93 \%)$ and FD (95\%) fruit were used.

\subsection{Total Polyphenol Content}

The total polyphenol content was determined using the Folin-Ciocalteu method. Methanolic murtilla fruit extract $(40 \mu \mathrm{L})$ was mixed with distilled water $(3.16 \mathrm{~mL})$ in a test tube and then $200 \mu \mathrm{L}$ of Folin-Ciocalteu reagent was added. After $5 \mathrm{~min}$ at $20{ }^{\circ} \mathrm{C}, 600 \mu \mathrm{L}$ of $20 \% \mathrm{Na}_{2} \mathrm{CO}_{3}$ was added to the reaction mixture, which was maintained at mentioned temperature for $120 \mathrm{~min}$ in darkness. The absorbance was measured at $765 \mathrm{~nm}$ using a spectrophotometer (Spectronic Genesys 5, Sweden), and the results were expressed as $\mathrm{mg}$ of gallic acid equivalent (GAE) per 100 gram of dry weight (d.w.).

\subsection{Total Anthocyanin Content}

The total anthocyanin content was determined by the $\mathrm{pH}$ difference method described by Sellappan, Akoh, and Krewer (2002). In two test tubes, $0.2 \mathrm{~mL}$ of methanolic murtilla fruit extract was mixed with $1.8 \mathrm{~mL}$ of both potassium chloride buffer solution at $\mathrm{pH} 1.0$ and sodium acetate buffer at $\mathrm{pH} 4.5$. The absorbance at 510 and 700 $\mathrm{nm}$ was measured for each extract-buffer mixture using a spectrophotometer (Spectronic Genesys 5, Sweden). The total anthocyanin content was determined using equations 1 and 2 , as follows:

$$
\begin{gathered}
\mathrm{A}=\left[\left(\mathrm{A}_{510}-\mathrm{A}_{700}\right)_{\mathrm{PH}=1.0}-\left(\mathrm{A}_{510}-\mathrm{A}_{700}\right)_{\mathrm{PH}=4.5}\right] \\
\mathrm{C}=\frac{\mathrm{A} \times \mathrm{MW} \times \mathrm{DF} \times 1000}{\varepsilon}
\end{gathered}
$$

where $\mathrm{C}=$ anthocyanin concentration $(\mathrm{mg} / \mathrm{L}), \mathrm{A}=$ anthocyanin absorbance, $\mathrm{MW}=$ molecular weight of the cyanidin-3-glucoside (449.2), DF = dilution factor (1.0) and $\varepsilon=$ molar extinction coefficient of the cyanidin-3-glucoside (26900). The result was expressed as $\mathrm{mg}$ of equivalent cyanidin-3-glucoside equivalent per 100 gram of dry weight (d.w.).

\subsection{Polyphenols and Anthocyanins by HPLC analysis}

The polyphenols and anthocyanins analyzed by HPLC in this study were based on the compounds previously identified by Rubilar et al. (2006), Shene et al. (2009) and Ruiz et al. (2010) in murtilla fruit and leaves. The Merck Hitachi HPLC system (LaChrom, Tokyo, Japan) contained an L-7100 pump and L-4250 UV-VIS detector. A $5 \mu \mathrm{m}$ C-18 RP Inertsil ODS-3 column (GL Sciences Inc, Tokyo, Japan) with a $250 \mathrm{~mm} \times 4.60 \mathrm{~mm}$ i.d. was utilized and maintained at $25{ }^{\circ} \mathrm{C}$. The sample extract was filtered through a $0.45 \mu \mathrm{m}$ filter, and $20 \mu \mathrm{L}$ was injected for the analysis of polyphenols and anthocyanins. The identification was confirmed both by comparison of their retention time with pure standards and by co-injection.

\subsubsection{Polyphenols}

HPLC analysis was performed according to the methodology described by Lopes-Lutz, Dettmann, Nimalaratne, and Schieber (2010) with modifications. A linear gradient solvent system consisting of $1 \%$ formic acid (A) and acetonitrile (B) was utilized at a flow rate of $1 \mathrm{~mL} / \mathrm{min}$ as follows: $0-2 \mathrm{~min}, 100 \% \mathrm{~A} ; 2-15 \mathrm{~min}, 80 \% \mathrm{~A} / 20 \% \mathrm{~B}$; $15-20 \mathrm{~min}, 70 \% \mathrm{~A} / 30 \% \mathrm{~B} ; 20-30 \mathrm{~min}, 40 \% \mathrm{~A} / 60 \% \mathrm{~B}$; and 30-35 min, $100 \% \mathrm{~A}$. The polyphenolic compounds were monitored at $280 \mathrm{~nm}$.

\subsubsection{Anthocyanins}

HPLC analysis was performed at a flow rate of $1 \mathrm{~mL} / \mathrm{min}$ using a linear gradient solvent system consisting of $1 \%$ formic acid (A) and acetonitrile (B) as follows: $0-2 \mathrm{~min}, 100 \% \mathrm{~A}$; 3-9 $\min , 90 \% \mathrm{~A} / 10 \% \mathrm{~B} ; 10-11 \mathrm{~min}, 80 \%$ 
$\mathrm{A} / 20 \% \mathrm{~B} ; 11-15 \min , 75 \% \mathrm{~A} / 25 \% \mathrm{~B} ; 16-30 \mathrm{~min}, 70 \% \mathrm{~A} / 30 \% \mathrm{~B}, 31-32 \mathrm{~min}, 60 \% \mathrm{~A} / 40 \% \mathrm{~B}$; and $33-35 \mathrm{~min}$, $100 \% \mathrm{~A}$. The anthocyanins were monitored at $525 \mathrm{~nm}$ (Lopes-Lutz et al., 2010).

\subsection{Antioxidant Activity by DPPH Assay}

Antioxidant activity was determined by free radical scavenging, which can be obtained by measuring the discoloration degree of a methanolic DPPH (2,2-diphenyl-1-picrylhydrazyl) solution (Rubilar et al., 2006; Alfaro et al., 2013). The initial absorbance of the DPPH solution ranged from 0.630 to 0.640 . An aliquot $(50 \mu \mathrm{L})$ of methanolic murtilla fruit extract was added to $1950 \mu \mathrm{L}$ of methanolic DPPH solution. The change in absorbance at $515 \mathrm{~nm}$ was measured at $30 \mathrm{~min}$. Trolox (6-hydroxy-2,5,7,8-tetramethylchroman-2-carboxylic acid) and a calibration curve were used to evaluate the DPPH scavenging ability of the methanolic murtilla fruit extract. The results were expressed as $\mu \mathrm{mol}$ Trolox equivalent per 100 gram of dry weight (d.w.).

\subsection{Antioxidant Activity by ABTS Assay}

Antioxidant activity was assessed by the inhibition of the free radical ABTS (2,2'-azino-bis-(3-ethilbenzothiazoline-6-sulfonic acid) according to Re et al. (1999). The $\mathrm{ABTS}^{+}$radical cation is formed during the reaction of ABTS and potassium. Then, the resulting blue-green colored $\mathrm{ABTS}^{+}$solution reacts directly with the antioxidant present in the sample. The reaction was carried out with $1 \mathrm{~mL}$ of the working $\mathrm{ABTS}^{+}$solution inside semi-micro cuvettes that were read at $734 \mathrm{~nm}$ (Reagent blank, $\mathrm{E}_{1}$ ). Methanolic murtilla fruit extract $(20 \mu \mathrm{L})$ and ethanol $(20 \mu \mathrm{L})$ were mixed with the working solution of $\mathrm{ABTS}^{+}$. After $6 \mathrm{~min}$, the absorbance was measured (Sample value, $E_{2}$ ) at $734 \mathrm{~nm}$. The difference between $E_{1}-E_{2}(\Delta E)$ was graphed versus the corresponding concentration. For this assay, a calibration curve was prepared using $20 \mu \mathrm{L}$ of ethanol and 20 $\mu \mathrm{L}$ of Trolox solutions (final concentrations between 0 and $15 \mu \mathrm{M}$ ) added to the working solution of $\mathrm{ABTS}^{+}$. The results were expressed as $\mu$ mol Trolox equivalent per 100 gram of dry weight (d.w.).

\subsection{Statistical Analysis}

The data were analyzed using one-way analysis of variance (ANOVA). The values obtained at $p<0.05$ were considered significant. The differences between means were determined using Tukey's multiple comparison tests and Student t-tests. The results are expressed as the means of the measurements and their corresponding standard deviations. The SPSS 20.0 software suite (SPSS Inc., Chicago, IL) was used to analyze the data.

\section{Results and Discussion}

\subsection{Total Polyphenol and Total Anthocyanin Contents in Fresh and Dried Murtilla Fruits}

The total polyphenol content (TPC) and the total anthocyanin content (TAC) in the dried fruit obtained by freeze drying (FD) and convective hot-air drying at $65{ }^{\circ} \mathrm{C}\left(\mathrm{HAD} 65^{\circ} \mathrm{C}\right)$ and $80^{\circ} \mathrm{C}\left(\mathrm{HAD} 80^{\circ} \mathrm{C}\right)$ were significantly different than the values recorded for the fresh murtilla fruit (Table 1). Freeze drying had a positive effect by increasing the TPC and TAC in dried fruits with respect to the fresh Red Pearl-INIA murtilla. In contrast, the hot-air drying treatments showed a decrease in the TPC and TAC, except the TPC for HAD $80{ }^{\circ} \mathrm{C}$, which increased.

Table 1. Total polyphenol content (TPC) and total anthocyanins content (TAC) in the Red Pearl-INIA variety of fresh and dried murtilla fruit

\begin{tabular}{ccc}
\hline Treatments & TPC $^{\mathbf{1}}$ & TAC $^{2}$ \\
\hline Fresh & $1149.2^{\mathrm{c}} \pm 30.1$ & $7.8^{\mathrm{b}} \pm 0.8$ \\
$\mathrm{HAD} 65^{\circ} \mathrm{C}$ & $720.9^{\mathrm{d}} \pm 41.1$ & $4.8^{\mathrm{bc}} \pm 0.7$ \\
$\mathrm{HAD} 80^{\circ} \mathrm{C}$ & $1462.5^{\mathrm{b}} \pm 113.5$ & $2.6^{\mathrm{c}} \pm 1.1$ \\
FD & $2192.4^{\mathrm{a}} \pm 181.9$ & $13.4^{\mathrm{a}} \pm 2.0$ \\
\hline
\end{tabular}

${ }^{1}$ Total polyphenol content as mg gallic acid equivalent per $100 \mathrm{~g}$ d.w.

${ }^{2}$ Total anthocyanin content as mg cyanidine-3-glucoside equivalent per $100 \mathrm{~g}$ d.w.

The data are expressed as the mean \pm the standard deviation of three replicates. Values with different superscripted letters within columns differ significantly and were tested by ANOVA and Tukey's HDS at $\mathrm{p}<$ 0.05. Abbreviations: hot-air drying at $65^{\circ} \mathrm{C}\left(\mathrm{HAD} 65^{\circ} \mathrm{C}\right)$ and $80^{\circ} \mathrm{C}\left(\mathrm{HAD} 80^{\circ} \mathrm{C}\right)$ and freeze drying (FD). 
Several authors have reported that freeze drying either slightly increases or retains higher TPC or TAC than the other drying techniques applied to berries and other fruits. According to Kwok et al. (2004), freeze drying maintained higher TPC and TAC concentrations in Saskatoon berries (Amelanchier alnifolia Nutt.) than other techniques, such as air-drying, vacuum microwave drying and combination techniques with both air and microwave vacuum drying. A similar result for the TPC in strawberries was observed when fresh fruit was subjected to convective air and freeze drying methods. The latter showed a tendency to maintain the initial values obtained from the fresh fruit of three different strawberry varieties (Böhm, Kühnert, Rohm, \& Scholze, 2006). Michalczyk, Macura, and Matuszak (2009) reported only a slight decrease or increase in TPC and TAC when freeze drying was applied to bilberry, strawberry and raspberry fruits, whereas there was a greater loss in TPC and TAC when air drying was applied. On the contrary, Mejia-Meza et al. (2010) reported that the total polyphenol glucoside and aglycone compounds were retained in higher concentrations in blueberries dried by vacuum microwave and combined drying methods (hot-air drying + vacuum microwave) than the fruits subjected to freeze drying.

The unusual increase in TPC and TAC exhibited by the murtilla fruit subjected to FD could be the result of changes in cell structure and the chemical degradation associated with freezing and subsequent sublimation. Aguilera et al. (2010) observed an increase in the dihydroxybenzoic acid content in dried lentils prepared by dehydration using a forced-air tunnel at $75 \pm 3{ }^{\circ} \mathrm{C}$ for $6 \mathrm{~h}$. Since this increase might originate from the disruption of cell walls during processing or the breakdown of insoluble phenolic compounds, it could have led to better extractability of these compounds.

Compared to the fresh fruit, a decrease in the TPC (37.3\%) and TAC (38.5\%) was observed in the dried fruit prepared by HAD $65{ }^{\circ} \mathrm{C}$, but for the murtilla fruit treated with HAD $80{ }^{\circ} \mathrm{C}$, the TPC increased $(21.4 \%)$ but the TAC decreased (66.7\%). Böhm et al. (2006) observed a 23.6 to $33.1 \%$ decreases in total polyphenols, depending on the strawberry variety, when convective hot-air drying $\left(\sim 60{ }^{\circ} \mathrm{C}\right.$ for $\left.220 \mathrm{~min}\right)$ was used. Furthermore, a decrease was observed for TPC (35.9\%) and TAC (73 and 63.5\%) in the Kent and Elsanta strawberry cultivars when convective hot-air $\left(70{ }^{\circ} \mathrm{C}\right.$ and air velocity of $\left.1 \mathrm{~m} \mathrm{~s}^{-1}\right)$ was applied (Wojdyło et al., 2009). According to Mejia-Meza et al. (2010), total phenolic glycosides and aglycones content were reduced by approximately $80 \%$ when raspberries were dried with air at $76.6^{\circ} \mathrm{C}$ for $4.5 \mathrm{~h}$ (final moisture content $\sim 5 \%$ ). Saskatoon berries (Amelanchier alnifolia Nutt. cv. Thiessen and Smoky) dried using convective air at $75{ }^{\circ} \mathrm{C}$ showed decreased TPC and TAC, ranging from 65.5 to $56.5 \%$ and 87.6 to $83.4 \%$, respectively (Kwok et al., 2004). The results of this study are consistent with those reported in the literature for berries dried using hot-air, except for the TPC, which increased with $\operatorname{HAD} 80^{\circ} \mathrm{C}$. However, when red grapes were dried using hot-air at $40{ }^{\circ} \mathrm{C}$ and a relative humidity of approximately $20 \%$, Serratosa, Marquez, Lopez-Toledano, Medina, and Merida (2011) hypothesized that the increase in the concentrations of the phenol compounds was a result of a) water evaporation, b) improved extraction from skins, and c) compound hydrolysis and/or biosynthesis. The decrease in polyphenol and anthocyanin contents after heat treatments is associated with degradation of the compounds, which generates smaller molecules, or in the case of the anthocyanins, produces molecular ring rupture (Furtado, Figueiredo, Chaves das Neves, \& Pina, 1993). Moreover, high temperatures can affect the stability of the anthocyanin monomers, resulting in polymerization (Markakis, 1982). These changes may affect the reactivity of the aromatic rings, which will be evident when the polyphenols are measured in the presence of Folin-Ciocalteu reagent.

\subsection{Polyphenols and Anthocyanins in Fresh and Dried Murtilla Fruit by HPLC Analysis}

The polyphenolic compounds identified in fresh, Red Pearl-INIA murtilla fruit (Table 2) were gallic acid, catechin, quercetin glucoside, myricetin, quercetin and kaempferol, which have also been reported by Rubilar et al. (2006), Shene et al. (2009) and Ruiz et al. (2010) for murtilla fruit and leaves. There were significant differences in the contents of these specific phenolic compounds between the fresh and dried fruit. 
Table 2. Polyphenol compounds measured by HPLC in fresh and dried Red Pearl-INIA murtilla fruit

\begin{tabular}{ccccc}
\hline $\begin{array}{c}\text { Polyphenol compound } \\
(\mathbf{m g} / \mathbf{1 0 0} \text { g d.w. })\end{array}$ & Fresh & HAD 65 ${ }^{\circ} \mathbf{C}$ & HAD 80 ${ }^{\circ} \mathbf{C}$ & FD \\
\hline Gallic acid & $0.51^{\mathrm{b}} \pm 0.07$ & $2.16^{\mathrm{ab}} \pm 0.15$ & $1.97^{\mathrm{ab}} \pm 0.50$ & $6.32^{\mathrm{a}} \pm 3.37$ \\
Catechin & $35.11^{\mathrm{ab}} \pm 0.41$ & $18.78^{\mathrm{b}} \pm 3.24$ & $43.57^{\mathrm{ab}} \pm 9.65$ & $69.91^{\mathrm{a}} \pm 30.99$ \\
Quercetin 3- $\beta$-D-glucoside & $157.17^{\mathrm{a}} \pm 26.42$ & $0.94^{\mathrm{b}} \pm 0.19$ & $1.73^{\mathrm{b}} \pm 0.56$ & $1.41^{\mathrm{b}} \pm 0.52$ \\
Myricetin & $14.07^{\mathrm{a}} \pm 5.42$ & $1.05^{\mathrm{b}} \pm 0.12$ & $1.11^{\mathrm{b}} \pm 0.15$ & $1.03^{\mathrm{b}} \pm 0.21$ \\
Quercetin & $0.66^{\mathrm{b}} \pm 0.26$ & $0.86^{\mathrm{ab}} \pm 0.18$ & $1.41^{\mathrm{a}} \pm 0.44$ & $0.24^{\mathrm{b}} \pm 0.17$ \\
Kaempferol & $0.84^{\mathrm{a}} \pm 0.05$ & $0.09^{\mathrm{bc}} \pm 0.01$ & $0.11^{\mathrm{b}} \pm 0.03$ & $0.02^{\mathrm{c}} \pm 0.01$ \\
Total polyphenols & $208.20 \pm 27.90$ & $23.97 \pm 3.43$ & $49.91 \pm 10.39$ & $79.02 \pm 30.58$ \\
\hline
\end{tabular}

The data are expressed as the mean \pm the standard deviation of three replicates. Values with different superscripted letters within rows differ significantly and were tested by ANOVA and Tukey's HDS at $\mathrm{p}<0.05$. Abbreviations: hot-air drying at $65^{\circ} \mathrm{C}\left(\operatorname{HAD} 65^{\circ} \mathrm{C}\right)$ and $80^{\circ} \mathrm{C}\left(\mathrm{HAD} 80^{\circ} \mathrm{C}\right)$ and freeze drying (FD).

The most abundant compound in the fresh fruit was quercetin 3- $\beta$-D-glucoside, which represented $75.4 \%$ of the identified compounds $(208.2 \mathrm{mg} / 100 \mathrm{~g}$ d.w.). An important decline in this glucoside was observed when the fresh fruit was subjected to $\operatorname{HAD} 65^{\circ} \mathrm{C}, \mathrm{HAD} 80^{\circ} \mathrm{C}$ and FD. Among the identified polyphenols, catechin was the compound that had the highest content in the murtilla fruit dried by any of the evaluated techniques (for HAD 65 ${ }^{\circ} \mathrm{C}, 78.3 \%$; for $\operatorname{HAD} 80{ }^{\circ} \mathrm{C}, 87.3 \%$; and for $\left.\mathrm{FD}, 88.5 \%\right)$. With respect to the fresh fruit content $(35.1 \mathrm{mg} / 100 \mathrm{~g}$ d.w.), the catechin concentration showed no significant increase for dried fruit prepared with HAD $80{ }^{\circ} \mathrm{C}$ and FD and no significant decrease with HAD $65{ }^{\circ} \mathrm{C}$ (Table 2). The gallic acid content in the fruit prepared by FD increased compared to the concentration in fresh fruit $(0.51 \mathrm{mg} / 100 \mathrm{~g}$ d.w.). For the HAD treatments, the gallic acid content in the dried fruit increased compared to the fresh fruit, but the values were not significantly different The quercetin 3- $\beta$-D-glucoside, myricetin and kaempferol concentrations decreased significantly in the dried fruit compared to the fresh fruit. The degradation of these three compounds during the drying process could be attributed to the formation of gallic acid and catechin, which were present at a higher concentration in the dried fruit compared to the fresh fruit. Wojdyło et al. (2009) reported an increase in the levels of (+)-catechin in dried strawberries after different drying processes, especially for the Elsanta cultivar, which was attributed to the depolymerized effect of the pro-anthocyanidins in strawberries and their conversion into elementary units. A significant increase in concentration in the dried fruit obtained by $\mathrm{HAD} 80^{\circ} \mathrm{C}$ was only observed for quercetin.

With respect to the fresh murtilla fruit $(208.2 \mathrm{mg} / 100 \mathrm{~g}$ d.w.), the total polyphenols by HPLC decreased upon treatment with HAD $65{ }^{\circ} \mathrm{C}, \mathrm{HAD} 80^{\circ} \mathrm{C}$ and $\mathrm{FD}$, as determined by HPLC (Table 2), but FD resulted in the highest retention $(79.0 \mathrm{mg} / 100 \mathrm{~g}$ d.w.) of these components. This result agrees with the reports by Wojdyło et al. (2009) and de Torres et al. (2010), who also reported that among different drying methods, freeze drying resulted in greater retention of total polyphenols and flavonols, as determined by HPLC in dried strawberries and Carménère grape skins, respectively.

The contents of the anthocyanin compounds in fresh and dried murtilla (Red Pearl-INIA variety) fruits are shown in Table 3.

Table 3. Anthocyanin compounds measured by HPLC in fresh and dried Red Pearl-INIA murtilla fruit

\begin{tabular}{ccccc}
\hline $\begin{array}{c}\text { Anthocyanin compound } \\
(\mathbf{m g} / \mathbf{1 0 0} \mathbf{g} \text { d.w. })\end{array}$ & Fresh & HAD 65 ${ }^{\circ} \mathbf{C}$ & HAD 80 ${ }^{\circ} \mathbf{C}$ & FD \\
\hline Cyanidin-3-glucoside & $0.106^{\mathrm{a}} \pm 0.006$ & $0.012^{\mathrm{b}} \pm 0.002$ & $0.017^{\mathrm{b}} \pm 0.003$ & $0.041^{\mathrm{b}} \pm 0.031$ \\
Peonidin-3-O-glucoside & $0.692^{\mathrm{a}} \pm 0.118$ & $0.078^{\mathrm{b}} \pm 0.035$ & $0.071^{\mathrm{b}} \pm 0.024$ & $0.147^{\mathrm{b}} \pm 0.095$ \\
Total anthocyanins & $0.799 \pm 0.115$ & $0.091 \pm 0.033$ & $0.089 \pm 0.027$ & $0.188 \pm 0.030$ \\
\hline
\end{tabular}

The data are expressed as the mean \pm the standard deviation of three replicates. Values with different superscripted letters within rows differ significantly and were tested by ANOVA and Tukey's HDS at $\mathrm{p}<0.05$. 
Abbreviations: hot-air drying at $65^{\circ} \mathrm{C}\left(\operatorname{HAD} 65^{\circ} \mathrm{C}\right)$ and $80^{\circ} \mathrm{C}\left(\operatorname{HAD} 80^{\circ} \mathrm{C}\right)$ and freeze drying $(\mathrm{FD})$.

The cyanidin-3-glucoside and peonidin-3-O-glucoside concentrations have been reported by Ruiz et al. (2010) in wild murtilla fruit. The concentrations of the individual anthocyanins in dried fruit decreased with respect to the fresh murtilla. Among the anthocyanin compounds, cyanidin-3-glucoside was the most stable compound and it was retained in the highest proportion (38.7\%) in the murtilla fruit dried using freeze drying. Additionally, FD retained the highest proportion $(21.2 \%)$ of peonidin-3-O-glucoside with respect to the initial concentration present in the fresh fruit.

Similar to the total polyphenols (Table 2), the drying temperatures employed herein resulted in a decrease in the total anthocyanin content with respect to the fresh murtilla fruit $(0.799 \mathrm{mg} / 100 \mathrm{~g} \mathrm{~d} . \mathrm{w}$.), which was determined by HPLC (Table 3). Similar effects above anthocyanins thermical stability has been reported by Keith and Powers (1965) and Furtado et al. (1993). Using HPLC-based measurements, the retention of total anthocyanins tends to be better for FD (23.5\%). Using HPLC-based quantification, studies with dried strawberries (Wojdyło et al., 2009) and Carménère grape skins (de Torres et al., 2010) showed that freeze drying provided greater retention of total anthocyanins with respect to other drying techniques. Additionally, dried cranberries obtained by freeze drying showed higher contents of three anthocyanins than the fruit dried by air and vacuum microwave drying (Leusink et al., 2010).

\subsection{Antioxidant Activity in Fresh and Dried Murtilla Fruit by DPPH and ABTS Assay}

The antioxidant activity, which was measured by DPPH and ABTS assays, in fresh and dried Red Pearl-INIA murtilla fruit dried by different techniques is presented in Table 4 .

Table 4. Antioxidant activity measured by DPPH and ABTS in fresh and dried Red Pearl-INIA murtilla fruit

\begin{tabular}{ccc}
\hline Treatments & DPPH & ABTS \\
\hline Fresh & $2111.1^{\mathrm{cA}} \pm 200.6$ & $2247.8^{\mathrm{cA}} \pm 7.8$ \\
HAD $65^{\circ} \mathrm{C}$ & $3567.4^{\mathrm{aA}} \pm 47.0$ & $3397.2^{\mathrm{aA}} \pm 20.1$ \\
HAD $80^{\circ} \mathrm{C}$ & $2945.4^{\mathrm{bA}} \pm 249.1$ & $2664.8^{\mathrm{bA}} \pm 293.5$ \\
FD & $3677.6^{\mathrm{aA}} \pm 27.0$ & $3162.9^{\mathrm{aB}} \pm 16.3$ \\
\hline
\end{tabular}

DPPH: antioxidant activity measured by the DPPH assay and expressed as $\mu$ mol Trolox equivalent per $100 \mathrm{~g}$ d.w.

ABTS: antioxidant activity measured by the ABTS assay and expressed as $\mu$ mol Trolox equivalent per $100 \mathrm{~g}$ d.w.

The data are expressed as the mean \pm the standard deviation of three replicates. Values with different lowercase superscripted letters within columns differ significantly and were tested by ANOVA and Tukey's HDS at $\mathrm{p}<$ 0.05 . The values with different superscripted capital letters within rows differ significantly by Student $t$-test at $\mathrm{p}$ $<0.05$. Abbreviations: hot-air drying at $65^{\circ} \mathrm{C}\left(\mathrm{HAD} 65^{\circ} \mathrm{C}\right)$ and $80^{\circ} \mathrm{C}\left(\mathrm{HAD} 80^{\circ} \mathrm{C}\right)$ and freeze drying $(\mathrm{FD})$.

The antioxidant activities from both assays (DPPH and ABTS) were expressed as $\mu$ mol Trolox equivalent per $100 \mathrm{~g}$ d.w. An increase in the DPPH and ABTS of the dried fruit compared to with fresh murtilla was observed for HAD $65{ }^{\circ} \mathrm{C}, \operatorname{HAD} 80^{\circ} \mathrm{C}$ and FD. The murtilla fruits dried by HAD 65 and $80^{\circ} \mathrm{C}$ showed similar antioxidant activity levels for both DPPH and ABTS. For the murtilla fruits dried by FD, the DPPH was higher than the ABTS. This activity difference could possibly be attributed to variation in the polyphenol composition, which benefitted one of the reactions used for determination of the antioxidant activity. The increase in the DPPH and ABTS values of the dried murtilla fruits (compared to the fresh fruit) treated by the drying techniques evaluated herein is not a typical behavior reported for other berries. The different drying methods evaluated for Saskatoon berry (Amelanchier alnifolia Nutt.), strawberry, raspberry and cranberry fruits have shown a decrease in antioxidant activity (Kwok et al., 2004; Böhm et al., 2006; Wojdyło et al., 2009; Leusink et al., 2010; Mejia-Meza et al., 2010). For the Saskatoon berries, the DPPH antioxidant capacity of the dried fruit compared to the fresh decreased by $41.3 \%$ and $73.9 \%$ upon application of freeze drying and convective air drying, respectively (Kwok et al., 2004). Moreover, Wojdyło et al. (2009) reported a significant decrease in the DPPH antioxidant activity when freeze drying $(12.8 \%)$ and convective air drying $(37.9 \%)$ methods were applied to strawberry fruits.

The increase in DPPH and ABTS antioxidant activities of the murtilla fruit after drying by HAD $65^{\circ} \mathrm{C}, \operatorname{HAD} 80$ 
${ }^{\circ} \mathrm{C}$ and FD represents a favorable effect. Reyes et al. (2009) also reported an increase in DPPH antioxidant activity $\left(\mathrm{EC}_{50}\right)$ and a decrease in polyphenols when murtilla fruits from ecotype 14-4 INIA from the Carillanca Genetic Bank were evaluated by vacuum and atmospheric freeze drying. Additionally, the antioxidant efficiency $\left(1 / \mathrm{EC}_{50}\right)$ was not significantly affected in dried blueberry fruits prepared by vacuum or atmospheric freeze drying (Reyes et al., 2011).

The increase in antioxidant activity observed herein could be related to changes in the composition of polyphenols and possibly associated with the increase in the aglycone compounds, such as gallic acid and catechin (Table 2). Mrkic, Cocci, Dalla Rosa, and Sacchetti (2006) reported a higher antioxidant activity of air dried $\left(50-100{ }^{\circ} \mathrm{C}, 25-90 \mathrm{~min}\right)$ broccoli with respect to the fresh vegetable. The authors explained this result by hypothesizing that there was an increase in compounds released from the matrix, hydrolytic phenomena during drying and polyphenol oxidation that resulted in oligomers with higher antioxidant activity than the native compounds. Serratosa et al. (2011) also reported an increase in the hydrophilic and lipophilic antioxidant activities in red grapes during the air drying process $\left(40{ }^{\circ} \mathrm{C}\right.$ and a relative humidity of approximately $20 \%$ ), which was related to the increase in phenol compounds.

\section{Conclusions}

The application of FD on the Red Pearl-INIA variety of fresh murtilla (Ugni molinae Turcz) fruits preserved both the total polyphenol content and the total anthocyanin content respect to fresh fruit. HAD $65^{\circ} \mathrm{C}, \mathrm{HAD} 80^{\circ} \mathrm{C}$ and FD produced a variation in the composition of the polyphenols and anthocyanin compounds within the fresh murtilla fruit. Compared to $\operatorname{HAD} 65^{\circ} \mathrm{C}$ and $\operatorname{HAD} 80^{\circ} \mathrm{C}$, freeze drying showed higher total polyphenols and anthocyanins by HPLC. The application of HAD $65^{\circ} \mathrm{C}, \mathrm{HAD} 80^{\circ} \mathrm{C}$ and FD showed a positive effect on the antioxidant activity because these drying techniques increased the DPPH and ABTS of the dried murtilla fruits in comparison to the fresh fruit. This increase could be explained by variations in the composition of polyphenolic compounds, such gallic acid and catechin. In conclusion, freeze drying is the best technique for the retention of polyphenolic compounds and the antioxidant activity of the Red Pearl-INIA variety of fresh murtilla fruit. Therefore, freeze drying is recommend over HAD at 65 or $80^{\circ} \mathrm{C}$ when bioactive polyphenol compounds need to be preserved in murtilla fruit.

\section{Acknowledgments}

The authors are grateful for the financial support provided by Project FONDEF AF10I1007 from CONICYT, Chile.

\section{References}

Aguilera, Y., Dueñas, M., Estrella, I., Hernández, T., Benítez, V., Esteban, R. M., \& Martín-Cabrejas, M. A. (2010). Evaluation of phenolic profile and antioxidant properties of Pardina lentil as affected by industrial dehydration. J Agric Food Chem., 58, 10101-10108. http://dx.doi.org/10.1021/jf102222t

Alfaro, S., Mutis, A., Palma, R., Quiroz, A., Seguel, I., \& Scheuermann, E. (2013). Study of polyphenols content and antioxidant activity in murtilla (Ugni molinae Turcz) fruits in function of genotype and harvest season. J Soil Sci Plant Nutr., 13, 67-78. http://dx.doi.org/10.4067/S0718-95162013005000007

Böhm, V., Kühnert, S., Rohm, H., \& Scholze, G. (2006). Improving the nutritional quality of microwave-vacuum dried strawberries: a preliminary study. Food Sci Technol Int., 12, 67-75. http://dx.doi.org/10.1177/1082013206062136

de Torres, C., Díaz-Maroto, M. C., Hermosín-Gutiérrez, I., \& Pérez-Coello, M. S. (2010). Effect of freeze-drying and oven-drying on volatiles and phenolic compositions of grape skin. Anal Chim Acta., 660, 177-182. http://dx.doi.org/10.1016/j.aca.2009.10.005

Furtado, P., Figueiredo, P., Chaves das Neves, H., \& Pina, F. (1993). Photochemical and thermal degradation of

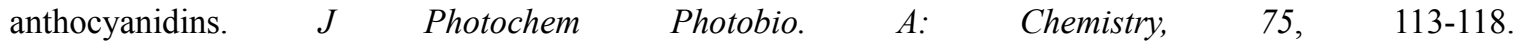
http://dx.doi.org/10.1016/1010-6030(93)80191-B

Grace, M. H., Massey, A. R., Mbeunkui, F., Yousef, G. G., \& Lila, M. A. (2012). Comparison of health-relevant flavonoids in commonly consumed cranberry products. $J$ Food Sci., 77, H176-H183. http://dx.doi.org/10.1111/j.1750-3841.2012.02788.x

Keith, E. S., \& Powers, J. J. (1965). Plant pigments, polarographic measurement and thermal decomposition of anthocyanin compounds. J Agric Food Chem., 13, 577-579. http://dx.doi.org/10.1021/jf60142a026

Kwok, B. H. I., Durance, T., \& Kitts, D. D. (2004). Dehydration techniques affect phytochemical contents and free radical scavenging activities of Saskatoon berries (Amerlachier alnifolia Nutt). J Food Sci., 69, 
SNQ122-SNQ126. http://dx.doi.org/ 10.1111/j.1365-2621.2004.tb13381.x

Leusink, G. J., Kitts, D., Yaghmaee, P., \& Durance, T. (2010). Retention of antioxidant capacity of vacuum microwave dried cranberry. J Food Sci., 75, 311-316. http://dx.doi.org/10.1111/j.1750-3841.2010.01563.x

Lewicki, P. P. (2006). Design of hot air drying for better foods. Trends Food Sci Tech., 17(4), 153-163. http://dx.doi.org/10.1016/j.tifs.2005.10.012

Lopes-Lutz, D., Dettmann, J., Nimalaratne, Ch., \& Schieber, A. (2010). Characterization and quantification of polyphenols in Amazon Grape (Pourouma cecropiifolia Martius). Molecules, 15, 8543-8552. http://dx.doi.org/10.3390/molecules15118543

López, J., Uribe, E., Vega-Gálvez, A., Miranda, M., Vergara, J., González, E., \& Di Scala, K. (2010). Effect of air temperature on drying kinetics, vitamin c, antioxidant activity, total phenolic content, non-enzymatic browning and firmness of blueberries variety O'Neil. Food Bioprocess Tech., 3, 772-777. http://dx.doi.org/10.1007/s11947-009-0306-8

Markakis, P. (1982). Stability of Anthocyanins in Foods. In Anthocyanins as Food Colors. In P. Markakis (Ed.). (pp. 163-180). New York, USA: Academic Press.

Mejia-Meza, E. I., Yañez, J. A., Remsberg, C. M., Takemoto, J. K., Davies, N. M., Rasco, B., \& Clary, C. (2010). Effect of dehydration on raspberries: polyphenol and anthocyanin retention, antioxidant capacity, and antiadipogenic activity. $J$ Food Sci., 75, 5-12. http://dx.doi.org/ 10.1111/j.1750-3841.2009.01383.x

Michalczyk, M., Macura, R., \& Matuszak, I. (2009). The effect of air-drying, freeze-drying and storage on the quality and antioxidant activity of some selected berries. J. Food Process Preserv., 33, 11-21. http://dx.doi.org/10.1111/j.1745-4549.2008.00232.x

Mrkic, V., Cocci, E., Dalla Rosa, M., \& Sacchetti, G. (2006). Effect of drying conditions on bioactive compounds and antioxidant activity of broccoli (Brassica oleracea L.). J Sci Food Agric., 86, 1559-1566. http://dx.doi.org/10.1002/jsfa.2554

Puente-Díaz, L., Ah-Hen, K., Vega-Gálvez, A., Lemus-Mondaca, R., \& Di Scala, K. (2013). Combined infrared-convective drying of murta (Ugni molinae Turcz) berries: kinetic modeling and quality assessment. Drying Technol., 31, 329-338. http://dx.doi.org/10.1080/07373937.2012.736113

Re, R., Pellegrini, N., Proteggente, A., Pannala, A., Yang, M., \& Rice-Evans, C. (1999). Antioxidant activity applying an improved ABTS radical cation decolorization assay. Free Radic Biol Med., 26, 1231-1237. http://dx.doi.org/10.1016/S0891-5849(98)00315-3

Reyes, A., Bubnovich, V., Bustos, R., Vasquez, M., Vega, R., \& Scheuermann, E. (2010), Comparative study of different process conditions of freeze drying of 'murtilla' berry. Drying Technol., 28, 1416-1425. http://dx.doi.org/10.1080/07373937.2010.482687

Reyes, A., Bustos, R., Vásquez, M. B., \& Scheuermann, E. (2009). Optimization of “murtilla” berry drying in an atmospheric freeze dryer. Chemical Engineering Transactions, 18, 183-188. http://dx.doi.org/10.3303/CET0918028

Reyes, A., Evseev, A., Mahn, A., Bubnovich, V., Bustos, R., \& Scheuermann, E. (2011). Effect of operating conditions in freeze-drying on the nutritional properties of blueberries. Int $J$ Food Sci Nutr., 62, 303-306. http://dx.doi.org/10.3109/09637486.2010.534078

Rodríguez, K., Ah-Hen, K., Vega-Galvez, A., López, J., Quispe-Fuentes, I., Lemus-Mondaca, R., \& Galvez-Ranilla, L. (2014) Changes in bioactive compounds and antioxidant activity during convective drying of murta (Ugni molinae T.) berries. Int J Food Sci Tech., 49(4), 990-1000. http://dx.doi.org/10.1111/ijfs.12392.

Rubilar, M., Jara, C., Poo, Y., Acevedo, F., Gutierrez, C., Sineiro, J., \& Shene, C. (2011). Extracts of maqui (Aristotelia chilensis) and murta (Ugni molinae Turcz.): sources of antioxidant compounds and $\alpha$-glucosidase/ $\alpha$-amylase inhibitors. $J$ Agric Food Chem., 59, 1630-1637. http://dx.doi.org/10.1021/jf103461k.

Rubilar, M., Pinelo, M., Ihl, M.; Scheuermann, E., Sineiro, J., \& Nuñez, M. J. (2006). Murtilla leaves (Ugni molinae Turcz) as a source of antioxidant polyphenols. J Agric Food. Chem., 54(1), 59-64. http://dx.doi.org/10.1021/jf051571j

Ruiz, A., Hermosin-Gutierrez, I., Mardones, C., Vergara, C., Herlitz, E., Dorau, C., ... von Baer, D. (2010). Polyphenols and antioxidant activity of calafate (Berberis microphylla) fruits and other native berries from 
southern Chile. J Agric Food Chem., 58, 6081-6089. http://dx.doi.org/10.1021/jf100173x

Scheuermann, E., Seguel, I., Montenegro, A., Bustos, R., Hormazábal, E., \& Quiroz, A. (2008). Evolution of aroma compounds of murtilla fruits (Ugni molinae Turcz) along storage. J Sci Food Agric., 88, 485-492. http://dx.doi.org/10.1002/jsfa.3111

Seguel, I., \& Montenegro, A. (2010). US PP21273 P3 Murtilla plant named Red Pearl-INIA (p. 5). Washington, USA: United States Patent and Trademark Office.

Sellappan, S., Akoh, C. C., \& Krewer, G. (2002). Phenolic compounds and antioxidant capacity of Georgia-grown blueberries and blackberries. $J$ Agric Food Chem., 50, 2432-2438. http://dx.doi.org/10.1021/jf011097r

Serratosa, M., Marquez, A., Lopez-Toledano, A., Medina, M., \& Merida, J. (2011). Changes in hydrophilic and lipophilic antioxidant activity in relation to their phenolic composition during the chamber drying of red grapes at a controlled temperature. $J$ Agric Food Chem., 59, 1882-1892. http://dx.doi.org/10.1021/jf1042536

Shene, C., Reyes, A., Villarroel, M., Sineiro, J., Pinelo, M., \& Rubilar, M. (2009). Plant location and extraction procedure strongly alter the antimicrobial activity of murtilla extracts. Eur Food Res Technol., 228, 467-475. http://dx.doi.org/10.1007/s00217-008-0954-3

Speisky, H., López-Alarcón, C., Gómez, M., Fuentes, J., \& Sandoval-Acuña, C. (2012). First web-based database on total phenolics and oxygen radical absorbance capacity (ORAC) of fruits produced and consumed within the south Andes region of South America. J Agric Food Chem., 60, 8851-8859. http://dx.doi.org/10.1021/jf205167k

Stojanovic, J., \& Silva, J. L. (2007). Influence of osmotic concentration, continuous high frequency ultrasound and dehydration on antioxidants, color and chemical properties of rabbiteye blueberries. Food Chem., 101, 898-906. http://dx.doi.org/10.1016/j.foodchem.2006.02.044

Wojdyło, A., Figiel, A., \& Oszmianski, J. (2009). Effect of drying methods with the application of vacuum microwaves on the bioactive compounds, color, and antioxidant activity of strawberry fruits. $J$ Agric Food Chem., 57, 1337-1343. http://dx.doi.org/10.1021/jf802507j

\section{Copyrights}

Copyright for this article is retained by the author(s), with first publication rights granted to the journal.

This is an open-access article distributed under the terms and conditions of the Creative Commons Attribution license (http://creativecommons.org/licenses/by/3.0/). 